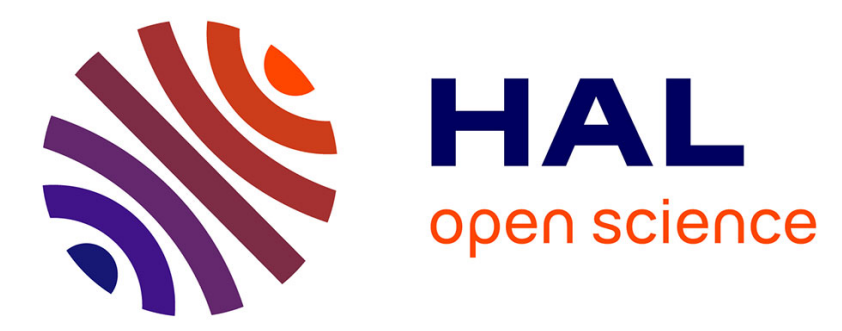

\title{
Generating Business Referrals for SMEs: The Contingent Value of CEOs' Social Capital
}

Barthelemy Chollet, Mickaël Géraudel, Caroline Danièle Mothe

\section{To cite this version:}

Barthelemy Chollet, Mickaël Géraudel, Caroline Danièle Mothe. Generating Business Referrals for SMEs: The Contingent Value of CEOs' Social Capital. Journal of Small Business Management, 2013, 52 (1), pp.79-101. 10.1111/jsbm.12034 . hal-00915173v2

\section{HAL Id: hal-00915173 \\ https://hal.science/hal-00915173v2}

Submitted on 13 Feb 2014

HAL is a multi-disciplinary open access archive for the deposit and dissemination of scientific research documents, whether they are published or not. The documents may come from teaching and research institutions in France or abroad, or from public or private research centers.
L'archive ouverte pluridisciplinaire $\mathbf{H A L}$, est destinée au dépôt et à la diffusion de documents scientifiques de niveau recherche, publiés ou non, émanant des établissements d'enseignement et de recherche français ou étrangers, des laboratoires publics ou privés. 


\section{Generating business referrals for SMEs: \\ the contingent value of $\mathrm{CEO} \mathrm{s}^{\prime}$ social capital}

\section{B Chollet, M Géraudel, C Mothe}

\section{Introduction}

Firms receive a referral when a third party recommends them to a previously unknown potential customer, which may result in additional business. Although business referrals are valuable for all types of firms (Kumar et al. 2010; Money et al. 1998; Provan 1984), SMEs should pay particular attention to this way of gaining customers. First, SMEs usually have only limited resources to dedicate to the search for new customers, and to marketing efforts in general. Positive word of mouth and recommendations are particularly cost-effective (Villanueva et al. 2008; Trusov et al. 2009) because they can occur in the absence of any effort from the firm. Second, due to their small size and the limited scope of their activities, SMEs generally have lower profiles than large firms, which makes reputation building difficult (Goldberg et al. 2003). As a result, sources of information about an SME are limited, making it difficult for potential customers to assess whether or not it would be profitable to do business with that firm. Opinions and information circulated by third parties increase a firm's prominence, thereby making it more attractive as a trustworthy supplier (Le and Nguyen 2009; Seevers et al. 2010).

The marketing literature on referral behaviors particularly focuses on current customers that are satisfied with the product as the most important source of referrals (Kumar et al. 2010). Nevertheless, several studies of small businesses suggest that another source might contribute substantially, either directly or indirectly, to the generation of business referrals: the personal relationships of the SME CEO. These studies found that CEOs use their 
personal networks of relationships to circulate favorable information in order to obtain more business for their firms (Johannisson 1996; Uzzi 1997; Jack 2005; Zhou et al. 2007). This particular contribution of social contacts owes to the fact that the contacts hold first-hand information about the CEO's reliability and may be motivated to transfer it to other individuals as a way of helping. Although these studies have made important contributions by highlighting the importance of social ties in favoring referral behaviors, questions that are crucial for business practice remain unanswered: why do some CEOs obtain more business referrals than others through their personal relationships? How can CEOs maximize referrals and thereby ensure business growth? The present study addressed these questions.

Our first objective was to examine which configurations of CEO social capital induce the most business referrals. To this effect, we use an individual approach to social capital, which focuses on the potential that social relationships offer for the circulation of information (Adler and Kwon 2002; Burt 1992; Inkpen and Tsang 2005). This approach can be used to capture differences between CEOs in terms of social capital and to determine how these differences may affect a CEO's potential to obtain business referrals. We argue that CEOs with strong ties and structural holes in their personal networks will benefit from more favorable word of mouth and therefore more business referrals. The underlying rationale is that maximizing business referrals through social ties basically requires two elements: an ability to circulate information far beyond the set of persons that the CEO already knows (structural holes) and the motivation to circulate this information (strong ties). By identifying the configurations of social capital that lead to more business referrals, we contribute to a better understanding of how SMEs may enhance their business performance.

The individual approach to social capital has already contributed to the study of SMEs by using similar variables to explain important outcomes, such as innovation, growth or export performance (Ellis 2000; Julien et al. 2004; Ozgen and Baron 2007; Zhou et al. 2007). 
However, this approach has left the complexity of social capital underexplored. Apart from notable exceptions focusing on entrepreneurial ventures (Stam and Elfring 2008; Vissa and Chacar 2009), the CEO's social capital has been considered an unequivocally beneficial factor, regardless of boundary conditions. However, CEOs are individuals who perceive, understand and react to their environment differently (Becherer and Maurer 1999; Ciavarella et al. 2004; Covin and Slevin 1989), which suggests that any benefits they may obtain from their social capital will also vary according to their personal characteristics.

Therefore, the second objective of our study was to investigate the characteristics of SME CEOs as contingent factors of social capital. In doing so, we respond to the call for further research into how actor-level characteristics affect the outcomes of social capital (Adler and Kwon 2002; Zhou et al. 2009). In line with recent work on the interaction between social capital and personality in organizational settings (Anderson 2008; Baer 2010; Zhou et al. 2009), we consider personality traits as a crucial factor affecting the impact of social capital in the context of SMEs. Our research refers to theories of information circulation through social ties (Burt 2005; Ferrin et al. 2006; Wong and Boh 2010), and we argue that during social interactions a CEO's social contacts pick up behavioral cues indicating positive or negative personality traits. These observations form the basis for judgments and assessments that will affect their willingness to recommend the CEO's company to other people and that will ultimately impact the quality of information circulating along social ties. As a result, the effect of social capital should be contingent on a CEO's personality.

In order to pursue these objectives, the paper is structured as follows. We first examine the mechanism of business referrals and their importance for SMEs. We then analyze CEOs' social capital in the light of the individual approach to social capital. This leads to hypotheses about the impact of the key dimensions of strength of ties and structural holes on business referrals, and on its contingency to personality traits. After presenting the methodology and 
data collection process, together with our sample of 408 CEOs of small and medium-sized manufacturing companies, we describe the results of the survey. They offer new insights about how one particular trait of the CEO, conscientiousness, moderates the effect of social capital in the circulation of favorable information: rather than intensifying the positive outcomes of high conscientiousness, social capital attenuates the negative outcomes of lower conscientiousness. We conclude the paper by discussing the implications and limitations of these findings.

\section{Theoretical framework}

\section{Business referrals in the context of SMEs}

Because they can significantly help the process of customer acquisition, business referrals have received considerable attention in the marketing literature. Although they are less controllable and manageable than marketing actions (e.g., direct mail, broadcast media), referrals have some serious advantages (Kumar et al. 2010; Chen et al. 2011; Trusov et al. 2009). First, their influence on attitudes and beliefs about a firm is much stronger (Villanueva et al. 2008). Information about a product, a service or a firm is indeed considered more credible by potential customers when it is transferred through referrals than when it comes from the firm itself (Anderson et al. 1994; Seevers et al. 2010). Second, referrals contribute to customer acquisition at a much lower cost than marketing actions (Trusov et al. 2009). Indeed, they often take place as a result of spontaneous information circulation from one person to the other rather than because of a firm's deliberate efforts. This argument is particularly crucial for SMEs as they tend to have limited resources to dedicate to gaining the attention of potential customers (Golberg et al. 2003).

Despite the great advantages of referrals, though, their impact on customer acquisition might vary with the type of purchasing decision. The fact that someone recommends a 
company to a potential customer does not necessarily lead the latter to become an actual customer. Business referrals seem to be especially valuable when very first-hand information is needed before making purchasing decisions (Anderson et al. 1994; Seevers et al. 2010). This is particularly the case in situations of business-to-business relationships with high uncertainty due to product complexity or the need for substantial mid- and long-term commitments (Bensaou and Anderson 1999; Mooi and Ghosh 2010). In these situations, establishing a new business relationship on the sole basis of publicly available information about the partner is risky (Podolny 1994). Screening and selecting a new business partner through third parties seems much safer, as these third parties can provide important knowledge about the trustworthiness and capabilities of the other firm (Li and Rowley 2002). Moreover, trust accumulated over a long period between the focal firm and some third party can simply be transferred to the newly formed dyad (Uzzi 1997). Similarly, a firm can expect the potential partner to be more cooperative if there is a third party, as any opportunistic behavior in their new relationship would create a serious threat of sanctions in the relationship it has already established with the third party (Podolny 1994).

In the context of SMEs, research has shown that referrals are based on the circulation of information about a firm's CEO at least as much (if not more) as about the firm in general. Studies of the specific case of entrepreneurial ventures are particularly enlightening in this respect. As newcomers to business, entrepreneurs tend to leverage the personal ties developed in earlier educational or professional situations (Hallen 2008). These individuals know the entrepreneur well and they can therefore compensate the lack of a track record by serving as referrals to other companies who would otherwise never consider the newborn company (Harrison et al. 1997; Larson 1992; Stuart et al. 1999; Shane and Cable 2002). As a result, Jack found that the mobilization of an entrepreneur's personal social ties is a key factor in obtaining orders through recommendations (Jack 2005). Similar mechanisms have also been 
observed among established SMEs, such as in Uzzi’s (1997) study of the New York apparel industry, which showed that the maintenance of close personal relationships by CEOs leads to business referrals. He found that it is possible for two companies whose CEOs do not know each other to quickly establish new commercial relationships if the two CEOs are engaged in a personal relationship with a third person who can recommend them doing business together (Uzzi 1997).

All these findings suggest that the unique combination of social ties around a CEO can make a serious difference by circulating favorable information leading to business referrals. Yet they do not really tackle the issue of why some CEOs have personal networks that lead to more referrals than others. By relying on the well established concept of social capital, our goal is to conceptualize the key differences across CEOs in terms of their personal networks so as to identify which configuration of personal relationships favors the best outcomes in terms of referrals.

\section{The benefits of individual social capital}

In the field of SMEs, the importance of personal relationships for business success has been examined from a number of perspectives. Some authors have referred to embeddedness (Granovetter 1985) to designate situations where business decisions appear to be governed by social framing and the structure of the network of social ties (Uzzi 1997; Yli-Renko and Autio 1998), whereas others have evoked social networks (BarNir and Smith 2002; Molina-Morales and Martinez-Fernandez 2010; Zhou et al. 2007) or social capital (Pirolo and Presutti 2010). In Asia, guanxi, a similar notion, has been shown to be an important aspect of business life, with implications for firm strategy (Carlisle and Flynn 2005; Chen and Chen 2004).

Adler and Kwon (2002) made a crucial contribution by showing how these approaches relate to the broader concept of social capital and contribute to two very different streams. One stream emphasizes the collective dimension of social relationships, seeing social capital 
as "an attribute of a social unit, rather than an individual" (Inkpen and Tsang 2005: 150), a public good that is shared, available to, and bringing benefits to all members of a group (Inkpen and Tsang 2005). Our paper builds on the second stream, which considers social capital from an individual point of view, as a concept that "helps explain the differential success of individuals and firms in their competitive rivalry" (Adler and Kwon 2002: 19). This stream sees social capital more as "a private good" (Inkpen and Tsang 2005: 150), based on the notion that a configuration of social ties surrounding an actor is highly idiosyncratic and can therefore bring unique advantages to one actor over others.

This stream of research clearly established that the ideal configuration of social capital has to be analyzed in terms of the quality and structure of the ties surrounding an actor rather than their number (Adler and Kwon 2002). Both these qualitative and structural dimensions have been discussed, raising two theoretical debates, one over the benefits of weak versus strong ties (Granovetter 1973; Hansen 1999) and the other over the benefits of dense networks of interconnected contacts versus sparse networks of unrelated others (Burt 1992).

The question of what level of tie strength and what type of structure bring the most positive outcomes has also been discussed in the field of SMEs. Differences among CEOs on these dimensions have been reported to explain variance in terms of firm growth (Stam and Elfring 2008; Vissa and Chacar 2009), innovation (Julien et al. 2004) and export performance (Ellis 2000; Zhou et al. 2007). These studies argue that such results account for the ability of social capital to give CEOs access to an important resource, namely information. For example, strong personal contacts in the same business help provide CEOs with an accurate picture of their competitive environment, making it easier for them to set prices (Ingram and Roberts 2000). Similarly, certain ties can facilitate the recognition of new business opportunities by providing a CEO with timely information about market changes (Ellis 2000; Ozgen and Baron 2007), and some ties make it easier for SMEs to source external knowledge 
(McEvily and Zaheer 1999). All these studies share the argument that personal contacts have knowledge of the environment which they can transfer to the CEO, and that some structures and levels of strength of a CEO's ties are more effective than others in this respect.

However, social capital can also help information travel in the opposite direction. A CEO's personal contacts have information about the CEO that they can transfer to other individuals who are potential customers or who can themselves circulate such information to potential customers. Although some studies investigating the types of structure and the levels of tie strength that give the best returns in terms of communicating favorable information have been carried out in organizational settings (Burt 2005; Ferrin et al. 2006; Wong and Boh 2010), there has been no such investigation with respect to SMEs. This void is all the more surprising given that such a study would help understand which configurations of social capital generate the most referrals for firms and therefore contribute to a better understanding of SME performance.

\section{Hypotheses}

\section{Social capital and business referrals}

The structure and strength of ties are important dimensions of social capital (Adler and Kwon 2002). Intuitively, having the highest number of direct contacts would be expected to result in the best access to resources and to more referrals. However, Burt (1992) contradicted this intuitive view, arguing that the number of non-redundant contacts is more important than the total number of contacts. This led him to introduce the concept of "structural holes", which he defined as gaps between non-redundant contacts. In Figure 1, Ego's network contains several structural holes. For example, Jack and Jane are non-redundant contacts: because there are no ties between them, they connect Ego to different others. On the other 
hand, Bob and Sue are redundant contacts: because they know each other and belong to the same social "clique", they indirectly connect Ego to the same contacts.

\section{Insert Figure 1}

An SME CEO whose network contains a lot of structural holes will be connected to many different zones of the social structure, thereby guaranteeing that information about his/her firm is disseminated to a maximum number of people. By contrast, a CEO with a very dense network (in the extreme case, everyone knows everyone else) will find it more difficult to spread information about his/her company beyond his/her network of direct contacts.

Numerous empirical studies have been carried out to test this theory, some of which specifically link structural holes in the CEO's network to SME performance. McEvily and Zaheer (1999) found that structural holes had a positive effect on a firm's acquisition of strategic capabilities, in particular because low redundancy in the network offers access to broader sources of knowledge. Similarly, in a study of Indian entrepreneurial ventures, Vissa and Chacar (2009) found that firm growth was higher among entrepreneurial teams with structural holes in their advice networks. Following an analysis of ventures in the open source software industry, Stam and Elfring (2008) reported that centrality, a measure that also captures network structure, impacts firm growth.

Overall, these studies recognized that structural holes have a positive impact on firm performance, but they were unable to determine whether this impact was due to the ability of structural holes to provide a firm with access to information and resources or to the fact that structural holes promote broader dissemination of favorable information and recommendations. As a result, it remains unclear whether the impact on firm performance is due to an information acquisition effect or an information diffusion effect. However, studies in the field of reputation building at work have produced convincing findings that structural 
holes favor the diffusion of favorable information. Following a similar argument to that of structural holes theory, Mehra et al. (2006) showed that a manager's leadership reputation is positively influenced by his/her central position in friendship networks within his/her organization. Similarly, Wong and Boh (2010) found that non-overlapping contacts lead to broader diffusion of information about a focal manager, resulting in enhanced reputation.

H1: The higher the number of structural holes in an SME CEO's network, the more business referrals he/she will obtain.

Another important dimension of SME CEOs' social capital is strength of ties, which is a function of interaction frequency, duration, emotional intensity, and reciprocity (Granovetter 1973; Zhou et al. 2009). Granovetter's argument is that if a CEO has strong ties with two persons who do not know each other, it is highly probable that they will develop a relationship over time (Granovetter 1973). Applying this principle to all of a CEO's relationships leads to the conclusion that individuals with strong ties tend to belong to rather dense networks in which resources circulate "in a closed circuit". Hence, it would be advantageous for an individual to create weak ties and to establish relationships with people he/she does not know and who belong to other social groups.

This argument suggests that structural holes, in Burt's sense, are more likely to exist between weak ties than between strong ties. However, other authors point out other reasons for the impact of strength of ties and provide arguments for a positive effect of strong ties (Ingram and Roberts 2000; Uzzi and Lancaster 2003). According to these arguments, it is more probable that a member of a CEO's network will recommend the CEO's firm if the tie is strong than if the tie is weak. First, a person with a weak tie to a CEO is less likely to be motivated to pass on information about the CEO's firm, whereas a person with a strong tie 
will generally be more motivated to support the CEO (Krackhardt 1992). Second, people with strong ties to a CEO often know what kind of resources and competences the CEO possesses (Borgatti and Cross 2003), increasing the probability that they will spread information about the CEO. In contrast, a weak tie implies less mutual knowledge and, probably, a smaller amount of substantial information to spread. Third, a person with whom a CEO has a strong tie is more likely to introduce a "positive bias" when spreading information about the CEO or his/her firm, relaying only more favorable aspects. This phenomenon is explained by people's tendency to over-estimate the qualities of others with whom they have strong ties because of the emotional components associated with such ties (Gershoff and Johar 2006).

These arguments may explain certain results reported in the literature. For example, in a qualitative study of 14 entrepreneurs, Jack (2005) reported that those who were able to build their firm's reputation mostly relied on strong ties based on family and friends. Similarly, in a study of medium sized firms that were selecting partners for international joint ventures, Wong and Ellis (2002) found that strong ties were more powerful than weak ties in conveying information about potential contacts.

H2: The stronger the ties in an SME CEO's network, the more business referrals he/she will obtain.

\section{Positive personality and business referrals}

By viewing networks as effective channels for spreading information, the individual perspective of social capital provides a framework for explaining how SMEs obtain business referrals. The better a CEO's network, the better the diffusion of information. However, the impact of information that travels through the network will differ according to whether it is favorable or unfavorable (Burt 2005). Because the opinion of a person within a CEO's 
network will depend on the CEO's characteristics and behavior, his/her personality traits should be taken into account alongside his/her personal networks (Baron and Markman 2000; Burt 2005). Whether or not favorable information is likely to circulate within the social structure will depend on these individual traits.

We consider personality traits to be fundamental characteristics of CEOs and believe that differences in personality traits between SME CEOs lead to differences in behavior. Several studies support this claim. For example, a CEO's personality has been shown to influence his/her company's chances of survival (Ciavarella et al. 2004), and a CEO's entrepreneurial orientation to determine firm performance (Becherer and Maurer 1999; Covin and Slevin 1989). Consistently, the present study follows the idea that a CEO's personality influences behaviors that affect both his/her SME and people's opinions in the network which will ultimately impact business referrals.

Of the many models that characterize personality traits, we selected four traits from the "big five" model (Costa and McCrae 1992; Digman 1990; Zhao and Seibert 2006): agreeableness, conscientiousness, extraversion, and openness to experience. These traits, which have been extensively tested by psychologists, have the advantage of providing a clear distinction between the personality aspects that are likely to be interpreted either very negatively or very positively by the people in contact with a $\mathrm{CEO}^{1}$. Moreover they have already been successfully applied to the context of entrepreneurship (Zhao and Seibert 2006).

Based on Zhao and Seibert (2006), these four traits can be defined as follows. Agreeableness indicates whether a person is considered trustworthy, altruistic and likely to take care of others, or, on the contrary, manipulative, self-centered, wary and lacking compassion. Conscientiousness indicates a person's degree of organization, his/her

\footnotetext{
${ }^{1}$ We did not select emotional stability, the fifth dimension of the big five, as previous research on how others make judgments based on personality traits has shown that emotional stability is the least observable trait. This is because emotional stability does not produce clear behavioral manifestations that can be observed in social interactions (Funder and Sneed 1993; Vazire 2010). Consequently, there is no theoretical foundation for assuming that this trait will be translated into favorable information diffusion.
} 
perseverance and motivation to work. People with low conscientiousness scores are disorganized and quickly discouraged. Extraversion describes the tendency to turn to the outside world. Extraverted people are dominant, energetic, active, talkative and enthusiastic; they enjoy group life and seek stimulation through contact with others. Introverted people prefer to spend more time alone and are rather reserved and independent. Openness to experience measures curiosity and willingness to search for new experiences and to explore original ideas. People with high scores on this dimension are creative, innovative, imaginative, thoughtful and non-conventional.

Several studies have addressed the impact of these personality dimensions on behavior (Lee et al. 2005; Paunonen 2003), on social status (Anderson et al. 2001) and on performance at work (Judge and Ilies 2002; Hurtz and Donovan 2000; Ones et al. 2007). Meta-analyses have shown that conscientiousness is a particularly important explanatory factor (Judge and Ilies 2002; Ones et al. 2007). When the other four dimensions operate, it is generally in a similar direction: they correlate positively with individual performance. However, most studies have noted performance in terms of evaluations made by supervisors (see the review by Ones et al. 2007). Thus, a person's personality is likely to affect his/her performance but may also influence how he/she is judged by other people. The notion that performance does not exist "in itself" but only through subjective evaluations is particularly relevant to our specific context of study: because they lack objective information, potential customers of a focal SME have to build an opinion based on their subjective perception of potential performance.

This consideration is consistent with another stream of research that shows that personality traits are subject to perception and strongly contribute to the types of judgment others make. For example, in a study of the formation of impressions at work, Flynn et al. (2001) found that people who are demographically different from their co-workers 
engendered more negative impressions. However, those who had high extraversion and selfmonitoring scores engendered more positive impressions than those with low scores for these traits. Similarly, Scott and Judge (2009) found that high core self-evaluations (a higher-order trait combining traits such as self-efficacy and self-esteem) were a factor of popularity in the workplace. On the contrary, individuals with low core self-evaluations were appraised negatively by others, resulting in lower popularity.

Taken together, these arguments suggest two complementary ideas: (a) personality traits are subject to perceptions by others and these perceptions partly drive their judgments; and (b) some traits are typically "positive personality traits" that lead to more favorable judgments, resulting in the circulation of positive information through personal relationships. In the case of SME CEOs, this should ultimately result in more business referrals. Thus:

H3a: The more an SME CEO is agreeable, the more business referrals he/she will obtain.

H3b: The more an SME CEO is conscientious, the more business referrals he/she will obtain.

H3c: The more an SME CEO is extraverted, the more business referrals he/she will obtain.

H3d: The more an SME CEO is open to experience, the more business referrals he/she will obtain.

\section{Positive personality as a contingent factor of social capital}

A growing body of literature suggests that the effect of social capital is linked to the characteristics of individuals. Burt (1992) and Ibarra (1992) found that women get less advantage than men from similar network positions. In the field of entrepreneurship, Stam and 
Elfring (2008) reported that centrality and the bridging ties connecting a founding team to other industries have a significant effect on business performance, but the strength of this effect depends on the founding team's level of entrepreneurial orientation. Similarly, Anderson (2008) reported that the average tie strength and the number of structural holes in a manager's network have a positive impact on the amount and diversity of information the manager can obtain, but this impact is stronger among managers with a high need for cognition. Similarly, Baer (2010) and Zhou et al. (2009) found that the impact of weak ties was moderated by personality traits (openness to experience and conformity, respectively). Extrapolating these findings to business referrals suggests that the amount of business referrals an SME CEO obtains from his/her network will depend on his/her personality traits ${ }^{2}$.

As stated above, some personality traits are perceived more positively than others (Scott and Judge 2009), and traits that are considered positive are more likely to lead to favorable information about a CEO being communicated along social ties. Thus, a social network that ensures good diffusion of information (structural holes and strong ties) may provide even greater benefits if the $\mathrm{CEO}$ at the hub of this network has personality traits that are perceived as positive. However, networks are not neutral vehicles for diffusing information, as the information they transmit tends to be attenuated or distorted during the diffusion process.

This attenuation and distortion are influenced by both structural holes and strong ties. Negative aspects of ego's personality circulate more easily and are more likely to become known by all the people linked to ego when ego is at the center of a dense network. In addition, the "echo" phenomenon (Burt 2005) leads to negative opinions being amplified and exaggerated during the circulation process. In Figure 1, the tie between Bob and Sue makes it

\footnotetext{
${ }^{2}$ Some authors focus on personality as an antecedent of social capital rather than as a moderator (Kalish and Robbins 2006; Kim and Kim 2007; Klein et al. 2004; Mehra et al. 2001; Oh and Kilduff 2008; Sasovova et al. 2010). Positioning personality as a moderator or an antecedent seems to depend on the exact trait being considered. Self-monitoring ("the extent to which individuals are willing and able to monitor and control their self-expressions in social situations", Mehra et al. 2001, 124) was found to be an antecedent in five of the six above-cited studies, but other traits have received very limited attention as antecedents.
} 
possible for negative information to circulate from one to the other and to become amplified during conservations. On the contrary, the absence of a tie between Jane and Jack may be beneficial to ego. For example, a CEO with very positive personality traits will benefit from the lack of a tie between Jane and Jack because they will spread information through different parts of the social structure. However, a CEO with very negative personality traits will benefit even more from this situation because the lack of a tie between Jane and Jack will attenuate the negative signal given by negative personality, as it cannot become a topic of conversation in the CEO's network. There can be no contagion from Jane to Jack, and no possibility for amplification through "echo" effects, as they do not know each other. Hence, it may be more beneficial for CEOs with negative personality traits to have numerous structural holes in their networks.

H4a: The positive relationship between structural holes and business referrals is stronger when an SME CEO is low on agreeableness

H4b: The positive relationship between structural holes and business referrals is stronger when an SME CEO is low on conscientiousness.

H4c: The positive relationship between structural holes and business referrals is stronger when an SME CEO is low on extraversion.

H4d: The positive relationship between structural holes and business referrals is stronger when an SME CEO is low on openness to experience.

As stated above, a strong tie creates a deliberate or unconscious tendency for a contact to over-estimate the qualities of a focal actor and to distort information (Gershoff and Johar 2006). Similarly, a strong tie may enhance the motivation for a contact to provide support and help to ego, regardless of what it may cost (energy, time, or legitimacy). In such a situation, a 
CEO with very positive personality traits might benefit from strong ties, as they will enhance the diffusion of positive information and thereby reinforce an already positive signal. However, CEOs with very negative personality traits might benefit even more because contacts with strong ties will tend to ignore negative signals and filter and distort information through a positively biased schema before passing it on to other contacts. As a result, they will attenuate the negativity of the signal. On the contrary, negative information that travels along weak ties is more likely to be transferred "as is", leading to poor outcomes in terms of business referrals. Consequently, strength of ties is likely to have the biggest effect on referrals for CEOs with low scores on positive personality traits.

H5a: The positive relationship between strength of ties and business referrals is stronger when an SME CEO is low on agreeableness

H5b: The positive relationship between strength of ties and business referrals is stronger when an SME CEO is low on conscientiousness.

H5c: The positive relationship between strength of ties and business referrals is stronger when an SME CEO is low on extraversion.

H5d: The positive relationship between strength of ties and business referrals is stronger when an SME CEO is low on openness to experience.

\section{Methodology}

\section{Data}

We tested our hypotheses on a sample of CEOs of manufacturing $\mathrm{SMEs}^{3}$ in HauteSavoie, France. Restricting a study's scope to one geographical area is common practice in the field (e.g., Camisón and Villar-López 2010; Madrid-Guijarro et al. 2009; Niskanen and

\footnotetext{
${ }^{3}$ We used the European Union's definition of an SME as a firm with fewer than 250 employees.
} 
Niskanen 2010; Van Auken et al. 2009) because it facilitates the data collection process. More importantly, it ensures relatively homogeneous environmental conditions, thereby minimizing the role of extraneous variables. This aspect is particularly important in studies of social capital (Aarstad et al. 2010; Molina-Morales and Martínez-Fernández 2010; McEvily and Zaheer 1999), as "the patterns of social capital are strongly conditioned by the social context where business partners are embedded' (Pirolo and Presutti 2010, 205).

The area we selected has one predominant cluster, the Arve Valley, which has a high density of small subcontracting firms and the largest concentration of precision engineering companies in Europe. These firms operate in a business-to-business environment, manufacturing mostly non-standard products and responding to the specific needs of corporate customers, such as original equipment manufacturers in the automotive or aerospace industries. In this type of environment, purchasing decisions are often quite complex (Shao et al. 2008) and businesses need more refined and reliable information than what is publicly available. These decisions are also often risky due to high uncertainty, which generates a need for particularly trustworthy sources of information (Uzzi 1997). As a result, business referrals in this context should be of particular importance for customer acquisition. Another feature of this area is that it has been described as a "Marshallian district", with a long tradition of interpersonal relationships acting as cement for inter-firm collaboration (Courlet et al. 1993). It has also received regular financial support from national, regional and local authorities in order to promote cooperation. These characteristics should clearly facilitate information circulation and encourage relying on informal sources to assess the reliability of other firms.

In December 2007, we sent an invitation to participate in the study to the CEOs of the 1581 manufacturing SMEs listed in the databases of the Haute-Savoie Chamber of Commerce and Thésame, an Arve Valley organization that provides support to local firms in the metal 
products, mechanical engineering and electronics industries. The invitation email included a cover letter explaining that the study was supported by the Chamber of Commerce and Thésame. After two follow-up emails, we received 535 completed questionnaires, 427 of which were completed by respondents who identified themselves as the CEOs of their firm. We removed a further 19 questionnaires from the sample due to missing data, which left us with a database of 408 CEOs. This gave a final response rate of $25.81 \%$, which is quite satisfactory compared with standards in the field for this type of study (Bartholomew and Smith 2006; Baruch and Holtom 2008).

As shown in Table 1, most of the respondents had a graduate degree (47.79\%), were male $(79.90 \%)$ and had had long tenure with their company (more than 10 years for $57.11 \%$ of them). $44.12 \%$ percent of the firms in the sample had fewer than 10 employees, $39.22 \%$ had between 10 and 49 employees, and $16.67 \%$ had between 50 and 249 employees. Most of the firms operated in the metal products $(25.25 \%)$ or electronics industries $(24.02 \%)$, followed by the chemical (18.38\%) and industrial machinery (13.48\%) industries. A comparison between the composition of the final sample and the parent population did not show any statistically significant differences in terms of firm size and industry.

\section{Insert Table 1}

\section{Measures}

Business referrals. We applied a newly developed scale that uses respondents' reports to capture the degree to which customer acquisition relies on referrals. We pre-tested an initial list of items with eight researchers in management and with a group of ten SME CEOs taken from the parent population. Purification of the initial set resulted in a three-item scale (translated from French): "People recommend my company to customers", "People strongly advise other firms to do business with my company", "My company obtains contracts thanks 
to favorable word of mouth". Respondents rated how much they agreed with each item on a six-point Likert scale ranging from "strongly disagree" to "strongly agree". For the data collected, the scale had a satisfactory Cronbach's Alpha of $0.779^{4}$. To the best of our knowledge, the only previous study to have measured self-assessed levels of business referrals is Seevers et al. (2010), which was published after we had collected our data. Excepting the specific wording for their target population (retail buyers in the golf industry), Seevers et al.'s items are very similar to ours.

Name generators. We used name generators to build the variables relating to the respondents' networks. This method requires respondents to identify the people with whom they have contact on various levels (e.g., friendship or advice). In line with previous studies (Rodan and Galunic 2004; Burt 1992), we used five name generators. Respondents were asked to give the names or initials of people they have contact with for (1) obtaining advice before making important decisions, (2) exchanging information on business trends and competition, (3) recruiting employees, and (4) finding solutions to technical problems. The fifth generator was a more open heading: "anybody you consider important for the management of your business and who did not fall into the previous categories". Each respondent could enter up to 18 names, and for each name the respondent was expected to answer a number of questions.

Structural holes. Structural holes can be measured in several ways; however, the most widely used measurement is aggregate constraint. It indicates the extent to which the relationships in a focal actor's network lead, directly or indirectly, to the same people (Burt 1992, 54-55). In other words, it expresses the extent to which a focal actor is surrounded by individuals who have connections with other people in the network. In this respect, it is strongly correlated with network density.

Burt (1992) defined the constraint exerted by an alter $\mathrm{j}$ on a focal actor $\mathrm{i}$ as:

\footnotetext{
${ }^{4}$ See Appendices for the Principal Components Analysis of business referrals.
} 


$$
c_{i j}=\left(p_{i j}+\sum_{q} p_{i q} p_{q j}\right)^{2}, \quad q \neq i, j
$$

where $\mathrm{p}_{\mathrm{ij}}$ is the proportion of all relations that contact $\mathrm{j}$ represents in i's network. $\Sigma_{\mathrm{q}} \mathrm{p}_{\mathrm{iq}} \mathrm{p}_{\mathrm{qj}}$ is the portion of i's relations with other contacts who are in turn connected to $\mathrm{j}$. It gives a measure of the importance of $\mathrm{j}$ in i's network. If this sum is very high, it means that the presence of $\mathrm{j}$ in i's network considerably reduces the number of structural holes. The aggregate constraint is obtained by summing all the constraints exerted by each individual alter in ego's network:

$$
c_{i}=\sum_{j} c_{i j}, \quad i \neq j
$$

In order to compute $c_{i j}$, we asked each respondent to indicate whether a pair of his/her contacts was connected, and to do this for every pair of contacts. These data were then converted into constraint values using UCINET VI software (Borgatti et al. 2002). If structural holes positively impact business referrals (as postulated in H1), then constraint should negatively impact this variable. Because constraint can range between 0 and 1 , and in order to facilitate interpretation, we used 1 - constraint to directly measure structural holes. This is in line with previous research (Rodan and Galunic 2004; McEvily and Zaheer 1999). Tie strength. Of the many measures that have been devised to assess tie strength (Marsden and Campbell 1984), the most commonly used are frequency of interactions and emotional closeness. However, Marsden and Campbell (1984) showed that emotional closeness gives higher validity than frequency of interactions because this latter variable is often a correlate of elements that are not connected with tie strength (e.g., geographical proximity). Therefore, we used emotional closeness in the present study. Our data collection tool asked respondents to position each of their listed contacts on a Likert scale ranging from "distant" to "especially close" (Burt 1992). A respondent's "strength of ties" score was the average of the scores obtained for all the contacts he/she listed. 
Personality traits. The "big five" scales have been frequently tested and validated. The International Personality Item Pool website contains translations of the most frequently used items in ten languages (Goldberg 1999). We selected six items for each dimension, so as to avoid cluttering the questionnaire and to maximize the response rate. Our pre-tests made it possible to ensure that all the items were well understood. Thus, we retained four personality variables: agreeableness $(\alpha=0.812)$, conscientiousness $(\alpha=0.774)$, extraversion $(\alpha=0.760)$ and openness to experience $(\alpha=0.757)$.

Controls. We controlled for several variables capturing key differences across SMEs. Firm size was measured in terms of number of employees, with the SMEs being divided into three categories: fewer than 10 employees, from 10 to 50 employees, and more than 50 employees. Two dichotomous variables were created: "fewer than 10 employees" and "from 10 to 50 employees". We also controlled for industry, using NES ${ }^{5}$ codes. We created a dichotomous variable for each category of industries mentioned in Table 1 (except "other manufacturing industries"). Other items on the questionnaire were used to measure characteristics of the CEOs, such as gender, tenure (number of years with the company) and education, for which we distinguished three categories (graduate degree, undergraduate degree, no degree). We used "graduate degree" and "undergraduate degree" as two dichotomous control variables.

\section{Results}

The summary statistics and correlation matrix for all the variables are presented in Table 2. The hypotheses were tested using hierarchical regressions ${ }^{6}$.

\section{The direct effects of social capital and personality}

\footnotetext{
${ }^{5}$ NES codes are a standard classification used by the French National Institute of Statistics and Economic Studies (INSEE).

${ }^{6}$ In line with Jaccard and Turrisi (2003), we mean-centered network and personality variables before processing the data, in order to avoid multicollinearity problems.
} 
With the stepwise introduction of the variables according to a hierarchical logic of regression, adding network variables (Model 2, Table 3) and then personality variables (Model 3) significantly enhanced the explanatory power of the model.

Our results support $\mathrm{H} 1$ and $\mathrm{H} 2$ (Model 2) with both stronger ties and larger numbers of structural holes in a CEO's network leading to more business referrals. This second result is in line with Burt (1992). H3 is also supported, as Agreeableness (H3a), Conscientiousness (H3b), Extraversion $(\mathrm{H} 3 \mathrm{c})$ and Openness to Experience (H3d) have a significant impact on business referrals. Overall, business referrals depend on the extent to which information about a CEO spreads through his/her personal network and on the nature of this information.

\section{Insert Table 2 and Table 3}

\section{Personality moderating the effect of social capital}

Model 4 (Table 3) includes all the variables that were introduced in the previous models, together with the interactions between the personality and network variables ${ }^{7}$. One personality trait - conscientiousness - significantly moderates the effect on business referrals of both structural holes and strength of ties. This particularity of conscientiousness is consistent with previous research. Of the "big five" traits, conscientiousness has been found to be the most important factor in individual performance (Judge and Ilies 2002; Ones et al. 2007). This trait signals reliability, motivation to fulfill commitments and willingness to pay attention to detail, and these aspects may be more important in the context of business relations than the other traits (agreeableness, extraversion and openness to experience).

Figure 2 depicts the interaction effects graphically (based on Aiken and West 1991). These graphs use the non-standardized coefficients to establish the regression slope,

\footnotetext{
${ }^{7}$ Correlations between network variables and personality traits are extremely weak $(-11.2 \%$ for the strongest correlation) These results provide additional evidence that personality traits should not be considered as antecedents. This is line with recent works (Baer 2010; Zhou et al. 2009; Anderson 2008).
} 
considering three cases: a high value for the moderating variable (one standard deviation above the mean), a low value for the moderating variable (one standard deviation below the mean), and a value equal to the mean for the moderating variable.

\section{Insert Figure 2}

The overall positive effect on business referrals of both structural holes and strength of ties was stronger among CEOs with lower conscientiousness. Hence, conscientiousness mitigates the positive effect of social capital, which indicates that networks are a source of information distortion and attenuation, as well as a source of information diffusion. CEOs with low conscientiousness (a signal that is negative for business) will get more business referrals if they have a network that is rich in structural holes because structural holes dampen the diffusion of negative signals. As the individuals in a CEO's network do not know each other, the negative signal cannot become a topic of conversation and will therefore lose its intensity. On the contrary, a low level of structural holes (high density and redundancy in the network) leads to intense circulation of the negative signal. The fact that information circulates very rapidly in a dense network will result in negative aspects being widely known by people connected to the CEO. Moreover, as well as spreading negative opinions, talk amplifies and exaggerates them (Burt 2005). In contrast, a very conscientious CEO will benefit from the amplification and exaggeration of opinions through a dense network (see the slightly negative slope for very conscientious individuals) because positive personality signals will be transmitted and amplified via conversations between individuals who know the CEO as well as each other.

We also found support for an interaction between strength of ties and conscientiousness. The impact of strength of ties was very high among CEOs with low 
conscientiousness and absent among CEOs with high conscientiousness. CEOs with low conscientiousness obtained more business referrals when they had strong ties (on the right in figure 3) and fewer business referrals when they had mainly weak ties. On the contrary, very conscientious CEOs obtained similar levels of business referrals no matter how strong (or weak) the ties in their networks. This is consistent with the notion that low conscientiousness is a negative signal that limits the diffusion of favorable information. When such negative information is transmitted along weak ties, it is likely to be transferred "as is". On the other hand, when it travels along strong ties, it is likely to be filtered and positively biased.

Table 4 summarizes the empirical support found for our hypotheses.

\section{Insert Figure 3}

\section{Insert Table 4}

\section{Discussion}

This study examined how a CEO's social capital and personality favor business referrals. In line with the individual approach to social capital (Adler and Kwon 2002; Burt 1992), we view social ties as important vehicles for spreading first-hand information about the CEO to potential customers (Uzzi 1997). Our findings offer several contributions. From a theoretical point of view, they highlight the relationship between information diffusion and networks that are rich in structural holes, whereas previous research focused on the role of this variable for SMEs in terms of information acquisition (McEvily and Zaheer 1999). Similarly, although strength of ties has been studied as an important variable affecting information acquisition (Julien et al. 2004; McEvily and Zaheer 1999), we provide evidence that it plays an important role in information diffusion. Thus, our study provides an original contribution to the debate over the "strength of strong ties" (Hansen 1999) versus the "strength of weak ties" (Granovetter 1973). 
Our research also contributes to current efforts to move beyond a "universal" theory of social capital. In line with a very recent stream of research (Anderson 2008; Baer 2010; Zhou et al. 2009), we argue that the value of social capital is contingent on personality. Building on research into the perception of personality traits (Flynn et al. 2001; Scott and Judge 2009), we tested a model in which a CEO's personality is a signal that is interpreted and referred to by contacts in his/her personal network. We found that positive personality traits have a direct positive effect on referrals. In addition, one of these personality traits, conscientiousness, moderates the impact of social capital. Conscientiousness signals that a focal actor is a reliable and hard-working person, and therefore a good job performer (Judge and Ilies 2002; Ones et al. 2007). Thus, it is not surprising that the conscientiousness of a CEO provides potential customers with a particularly valuable indication of his/her expected reliability in business.

A much more insightful finding lies in the way conscientiousness moderates the effect of social capital. Social capital (strong ties and structural holes) appears to be very beneficial for CEOs with low conscientiousness but almost neutral for CEOs with high conscientiousness. In other words, rather than intensifying the benefits accruing from high conscientiousness, social capital compensates for the negative reputation effect that low conscientiousness could create. Strong ties seem to involve a certain "bias" in the spread of information, with contacts disseminating favorable information and endorsing a CEO even when the initial signal is negative. Similarly, structural holes between contacts can prevent negative signals being propagated contagiously from one group of contacts to another, thereby reducing the likelihood of "echo" effects. This is very beneficial for CEOs with low conscientiousness, but not particularly advantageous for CEOs with high conscientiousness. Taken together, these results indicate that social ties must be seen as channels that alter information as it travels through them, thereby offering a more complex view of the individual approach to social capital.

These findings on personality as a contingent factor open new research avenues about the relationships between social capital and personality. Some studies have taken a different approach 
from ours, focusing on personality as an antecedent of social capital, rather than as a moderator. They found that traits such as self-monitoring (e.g., Kim and Kim 2007; Mehra et al. 2001; Oh and Kilduff 2008; Sasovova et al. 2010) or neuroticism (Kalish and Robbins 2006; Klein et al. 2004) lead to specific structures of personal networks. The coexistence of these studies with approaches positing other traits as moderators (Anderson 2008; Baer 2010; Zhou et al. 2009) reveals a need for theoretical clarification. Future research should consider models including some traits as antecedents of social capital (in particular, those capturing skills for or orientation toward socialization, e.g., self-monitoring) and other traits as moderators (those that are independent from socialization and more relevant to task-related dimensions, e.g., openness to experience or conscientiousness).

Future research should also examine the processes through which a person's opinion makes him/her more or less likely to recommend a CEO. This could be done by collecting information from CEOs' social contacts, rather than from CEOs themselves. Such studies would also address one of the limitations of the present study and therefore strengthen the validity of our results. Although relying on the self-evaluation of CEOs to assess business referrals is now a well established approach (Seevers et al. 2010), it entails some risk of bias due to differences in perceptions.

Finally, further research is needed before our results can be generalized. As in any survey, a limited response rate entails a risk of poor fit between the sample and the parent population. Although our response rate was satisfactory compared with standards in the field (Bartholomew and Smith 2006; Baruch and Holtom 2008), we checked for possible differences between respondent and non-respondent firms. Our analyses revealed no significant differences in terms of industry and firm size, suggesting that our sample is representative of the parent population. The generalizability of the results from this population to other contexts is less clear. We studied manufacturing SMEs operating in a business-to-business environment, where informal sources of information about a firm are particularly valuable in the process of making purchasing decisions. 
Similar studies in the context of much simpler purchasing decisions may lead to very different results.

In a similar vein, the benefits of individual social capital are highly dependent on the social context at a broader level (Adler and Kwon 2002) and our findings are based on a geographically restricted industrial cluster, as is the case for many other studies of social capital among SMEs (Molina-Morales and Martinez-Fernandez 2010; Pirolo and Presutti 2010). Our results should therefore be interpreted in the light of the particular social context of our study. In clusters, which are characterized by higher mutual trust and cooperation (Chetty and Agndal 2008; Cooke et al. 2005), the observed benefits of individual social capital (our research question) may be fueled by the pre-existing high level of collective social capital (our context). Moreover, local institutions usually play an important part in promoting collaboration and provide resources to make this possible (Fromhold-Eisebith 2005; Gilly and Wallet 2001). Another aspect that makes clusters favorable environments for business referrals through social ties is that physical proximity and collocation make it easier for CEOs to have frequent face-to-face interactions (Chetty and Agndal 2008). Therefore, it would be interesting to replicate our study in areas with a much lower concentration of SMEs, less specialization and less active local institutions. In such contexts, it would be reasonable to hypothesize that individual social capital would have a lower impact on business referrals due to the absence of collective social capital. A comparison of two areas would contribute to a better understanding of how levels of social capital (individual and collective) interact, an aspect that was pinpointed by Ibarra et al. (2005) as one of the future challenges in the field.

\section{References}

Aarstad, J., Haugland, S. A., and A. Greve (2010). "Performance Spillover Effects in Entrepreneurial Networks: Assessing a Dyadic Theory of Social Capital," Entrepreneurship Theory and Practice, 34(5), 1003-1019.

Adler, P., and S.-W. Kwon (2002). "Social Capital: Prospects for a New Concept," Academy of Management Review, 27 (1), 17-40. 
Aiken, L. S., and S. G. West (1991). Multiple Regression: Testing and Interpreting Interactions. London: Sage Publications.

Anderson, J.C., H. Hakansson, and J. Johanson (1994). "Dyadic Business Relationships Within a Business Network Context," Journal of Marketing, 58, 1-15

Anderson, C., O. P. John, D. Keltner, and A. M. Kring (2001). "Who Attains Social Status? Effects of Personality and Physical Attractiveness in Social Groups," Journal of Personality \& Social Psychology, 81, 116-132.

Anderson, M.H. (2008)."Social Networks and The Cognitive Motivation to Realize Network Opportunities: A study of managers' Information Gathering Behaviors," Journal of Organizational Behavior, 29, 51-78.

Baer, M. (2010). "The Strength of Weak-Ties Perspective on Creativity: A Comprehensive Examination and Extension", Journal of Applied Psychology, 95(3), 592-601.

BarNir, A. and K.A. Smith (2002). "Interfirm Alliances in the Small Business: The Role of Social Networks," Journal of Small Business Management, 40 (3), 219-232.

Baron, R.A., and G.D. Markman (2000). "Beyond Social Capital: How Social Skills Can Enhance Entrepreneurs' Success," Academy of Management Executive, 14(1), 106-116.

Bartholomew, S., and A.D. Smith (2006). "Improving Survey Response Rates from Chief Executive Officers in Small Firms: The Importance of Social Networks," Entrepreneurship Theory and Practice, 30 (1), 83-96.

Baruch, Y, and B.C. Hotlom (2008). "Survey Response Rate Levels and Trends in Organizational Research," Human Relations, 61(8), 1139-1160.

Becherer, R. C., and J. G. Maurer (1999). "The Proactive Personality Disposition and Entrepreneurial Behavior among Small Company Presidents," Journal of Small Business Management, 37 (1), 28-36.

Bensaou, M., and E. Anderson (1999). "Buyer-Supplier Relations in Industrial Markets: When Do Buyers Enter the Trap of Making Idiosyncratic Investments?", Organization Science, 10(4), 460-481.

Borgatti, S. P., and R. Cross (2003). "A Relational View of Information Seeking and Learning in Social Networks," Management Science, 49 (4), 432-445.

Borgatti, S. P., M.G. Everett, and L.C. Freeman (2002). Ucinet for Windows: Software for Social Network Analysis, Harvard: Analytic Technologies.

Burt, R. S. (1992). Structural Holes: the Social Structure of Competition. Cambridge: Harvard University Press.

Burt, R. S. (2005). Brokerage and Closure: An Introduction to Social Capital. New-York: Oxford University Press.

Camisón, C., and A. Villar-López (2010). "Effect of SMEs' International Experience on Foreign Intensity and Economic Performance: The Mediating Role of Internationally Exploitable Assets and Competitive Strategy", Journal of Small Business Management, 48(2), 116151.

Carlisle, E., and D. Flynn (2005). "Small Business Survival in China: Guanxi, Legitimacy, and Social Capital," Journal of Developmental Entrepreneurship, 10(1), 79-96.

Chen, X.-P., and C. C. Chen (2004). "On the Intricacies of the Chinese Guanxi: A Process Model of Guanxi Development," Asia Pacific Journal of Management, 21 (3), 305-324.

Chen, Y., Wang, Q., and J. Jinhong (2011). "Online Social Interactions: A Natural Experiment on Word of Mouth Versus Observational Learning", Journal of Marketing Research, XLVIII, $238-254$

Chetty, S., and H. Agndal (2008). "Role of Inter-Organizational Networks and Interpersonal Networks in an Industrial District", Regional Studies, 42 (2), 175-187.

Ciavarella, M. A., A.K. Buchholtz, C.M. Riordan, R.D. Gatewood, and G.S. Stokes (2004). "The Big Five and Venture Survival: Is There a Linkage?," Journal of Business Venturing, 19, 465-483. 
Cooke, P., N. Clifton, and M. Oleaga (2005). "Social Capital, Firm Embeddedness and Regional Development," Regional Studies, 39 (8), 1065-1077.

Costa, P. T., and R.R. McCrae (1992). "Normal Personality Assessment in Clinical Practice: The NEO Personality Inventory," Psychological Assessment, 4 (1), 5-13.

Courlet, C., B. Pecqueur, and B. Soulage (1993). "Industrie et Dynamiques de Territoires", Revue d'Economie Industrielle, 64, 7-21.

Covin, J. G., and D.P. Slevin (1989). "Strategic Management of Small Firms in Hostile and Benign Environments," Strategic Management Journal, 10 (1), 75-87.

Digman, J. M. (1990). "Personality Structure: Emergence of the Five-Factor Model," Annual Review of Psychology, 41 (1), 417-440.

Ellis, P. (2000). "Social Ties and Foreign Market Entry," Journal of International Business Studies, 31 (3), 443-469.

Ferrin, D.L., K.T. Dirks, and P.P Shah (2006). "Direct and Indirect Effects of Third-Party Relationships on Interpersonal Trust," Journal of Applied Psychology, 91(4), 870-883.

Flynn, F.J., J.A. Chatman, and S.E. Spataro (2001). "Getting to Know You: The Influence of Personality on Impressions and Performance of Demographically Different People in Organizations", Administrative Science Quarterly, 46 (3), 414-442.

Fromhold-Eisebith, M. (2005). "How to Institutionalize Innovative Clusters? Comparing Explicit Top-Down and Implicit Bottom-Up Approches," Regional Studies, 34 (8), 1250-1268.

Funder, D.C., and C.D. Sneed (1993). "Behavioral Manifestations of Personality: An Ecological Approach to Judgmental Accuracy," Journal of Personality \& Social Psychology, 64 (3), 479-490.

Gershoff, A. D., and G.V. Johar (2006). "Do You Know Me? Consumer Calibration of Friends' Knowledge," Journal of Consumer Research, 32, 496-503.

Gilly, J.P., and F. Wallet (2001). "Forms of Proximity, Local Governance and the Dynamics of Local Economic Spaces: The Case of Industrial Conversion Processes," International Journal of Urban and Regional Research, 25 (3), 553-570.

Goldberg, L.R. (1999). "A Broad-Bandwidth, Public Domain, Personality Inventory Measuring the Lower-Level Facets of Several Five-Factor Models". In I. Mervielde, I. Deary, F. De Fruyt, and F. Ostendorf (Eds.), Personality Psychology in Europe, (7), 7-28. Tilburg, The Netherlands: Tilburg University Press.

Goldberg, A. I., G. Cohen, and A. Fiegenbaum (2003). "Reputation Building: Small Business Strategies for Successful Venture Development," Journal of Small Business Management, 41, 168-186.

Granovetter, M. (1973). "The Strength of Weak Ties," American Journal of Sociology, 78 (6), 1360-1380.

Granovetter, M. (1985). "Economic Action and Social Structure: the Problem of Embeddedness," American Journal of Sociology, 91(3), 481-510.

Hallen, B.L (2008). "The Causes and Consequences of the Initial Network Positions of New Organizations: From Whom Do Entrepreneurs Receive Investments?," Administrative Science Quarterly, 53(4), 685-718.

Hansen, M.T. (1999). "The Search Transfer Problem: The Role of Weak Ties in Sharing Knowledge across Organizational Sub-Units," Administrative Science Quarterly, 44, 82111.

Harrison, R.T, M. R. Dibben, and C.M. Mason (1997). "The Role of Trust in the Informal Investor's Investment Decision: An Exploratory Analysis," Entrepreneurship: Theory and Practice, 21(4), 63-81.

Hurtz, G. M., and J.J. Donovan (2000). "Personality and Job Performance: The Big Five Revisited," Journal of Applied Psychology, 85, 869-879.

Ibarra, H. (1992). "Homophily and Differential Returns: Sex Differences in Network Structure and Access in an Advertising Firm", Administrative Science Quarterly, 37 (3), 422-447. 
Ibarra, H., M. Kilduff, and W. Tsai (2005). "Zooming In and Out: Connecting Individuals and Collectivities at the Frontiers of Organizational Network Research," Organization Science, 16(4), 359-371

Ingram, P., and P.W. Roberts (2000). "Friendships among Competitors in the Sydney Hotel Industry," American Journal of Sociology, 106 (2), 387-424.

Inkpen, A.,C. and E.W.K. Tsang (2005). "Social Capital, Networks, and Knowledge Transfer," Academy of Management Review, 30 (1), 146-165.

INSEE (2010). available at http://www.insee.fr/fr/regions/

Jaccard, J., and R. Turrisi (2003). Interaction effects in multiple regression, Thousand Oaks: Sage.

Jack, S. L. (2005). "The Role, Use and Activation of Strong and Weak Network Ties: A Qualitative Analysis," Journal of Management Studies, 42, 1233-1259.

Johannisson, B. (1996). "The Dynamics of Entrepreneurial Networks," in Frontiers of Entrepreneurship Research. Ed. P.D. Reynolds, S. Birley, J.E. Butler, W.D. Bygrave, P. Davidsson, W.B. Gartner, and P.P. McDougall, MA, Babson College: Babson Park, 253267.

Judge, T. A., and R. Ilies (2002). "Relationship of Personality to Performance Motivation: A Meta-Analytic Review," Journal of Applied Psychology, 87, 797-807.

Julien, P., E. Andriambeloson, and C. Ramangalahy (2004). "Networks, Weak Signals and Technological Innovations among SMEs in the Land-Based Transportation Equipment Sector," Entrepreneurship \& Regional Development, 16 (4), 251-269.

Kalish, Y., and G. Robbins (2006). "Psychological Predispositions and Network Structure: The Relationship between Individual Predispositions, Structural Holes and Network Closure", Social Networks, 28, 56-84.

Krackhardt, D. (1992). "The Strength of Strong Ties: the Importance of Philos in Organizations", in Networks and Organizations: Structure, Form and Action, Ed. N. Nohria, and R.G. Eccles. Boston: Harvard Business School Press, 216-239.

Kim, S-K., and M-J. Kim (2007). "Mentoring Network and Self-Monitoring Personality", Management Revue, 18(1): 42-54.

Klein, K. J., Lim, B., Saltz, J. L., and D.M. Mayer (2004). "How Do They Get There? An Examination of the Antecedents of Centrality in Team Networks", Academy of Management Journal, 47, 952-963.

Kumar, V., J. A. Petersen, and R. P. Leone (2010). "Driving Profitability by Encouraging Customer Referrals: Who, When, and How," Journal of Marketing, 74 (5), 1-17.

Larson, G (1992). "Network Dyads in Entrepreneurial Settings: A Study of the Governance of Exchange Relationships, " Administrative Science Quarterly, 37(1), 76-104.

Le, N. T.B., and T. V. Nguyen (2009). "The Impact of Networking on Bank Financing: The Case of Small and Medium-Sized Enterprises in Vietnam," Entrepreneurship: Theory \& Practice, 33 (4), 867-887.

Lee, K., M.C. Ashton, and K.-H Shin (2005). "Personality Correlates of Workplace Anti-Social Behavior," Applied Psychology: An International Review, 54, 81-98.

Li, S.X., and T.J. Rowley (2002). "Picking the Best Mates: Evaluating the Capabilities and Reliability of Interorganizational Partners," Academy of Management Journal, 45, 11041119.

Madrid-Guijarro, A., Garcia, D., and H. Van Auken (2009). "Barriers to Innovation among Spanish Manufacturing SMEs", Journal of Small Business Management, 47(4), 465-488.

Marsden, P., and C. Campbell (1984). "Measuring Tie Strength," Social Forces, 63 (2), 482-501.

McEvily, B., and A. Zaheer (1999). "Bridging Ties: a Source of Firm Heterogeneity in Competitive Capabilities," Strategic Management Journal, 20 (12), 1133-1156.

Mehra, A., M. Kilduff, and D.J. Brass (2001). "The Social Networks of High and Low SelfMonitors: Implications for Workplace Performance," Administrative Science Quarterly, 46 (1), 121-146. 
Mehra, A., A.L. Dixon, D.J. Brass, and B. Robertson (2006). "The Social Network Ties of Group Leaders: Implications for Group Performance and Leader Reputation," Organization Science, 17, 64-79.

Molina-Morales, F.X., and M. T. Martinez-Fernandez (2010). "Social Networks: Effects of Social Capital on Firm Innovation," Journal of Small Business Management, 48(2), 258-279.

Money, R.B., M.C. Gilly, and J.L. Graham (1998). "Explorations of National Culture and Wordof-Mouth Referral Behavior in the Purchase of Industrial Services in the United States and Japan", Journal of Marketing, 62, 76-87

Mooi, E., and M. Ghosh (2010). "Contract Specificity and Its Performance Implications", Journal of Marketing, 74(2), 105-120.

Niskanen, M., and J. Niskanen (2010). "Small Business Borrowing and the Owner-Manager Agency Costs: Evidence on Finnish Data," Journal of Small Business Management, 48(1), $16-31$.

Oh, H., and M. Kilduff (2008). "The Ripple Effect of Personality on Social Structure: Self Monitoring Origins of Network Brokerage," Journal of Applied Psychology, 93(5), 11551164.

Ones, D. S., S. Dilchert, C. Viswesvaran, and T.A. Judge (2007). "In Support of Personality Assessment in Organizational Settings," Personnel Psychology, 60, 995-1027.

Ozgen, E., and R.A. Baron (2007). "Social Sources of Information in Opportunity Recognition: Effects of Mentors, Industry Networks, and Professional Forums," Journal of Business Venturing, 22 (2), 174-192.

Paunonen, S.V. (2003). "Big Five Factors of Personality and Replicated Predictions of Behavior," Journal of Personality and Social Psychology, 84 (2), 411-424.

Pirolo, L., and M. Presutti (2010). "The Impact of Social Capital on the Start-ups' Performance Growth," Journal of Small Business Management, 48 (2), 197-227.

Podolny, J. M. (1994). "Market Uncertainty and the Social Character of Social Exchange," Administrative Science Quarterly, 39(3), 458-483.

Provan, K.G. (1984). "Technology and Interorganizational Activity as Predictors of Client Referrals," Academy of Management Journal, 27(4), 811-829.

Rodan, S., and C. Galunic (2004). "More than Network Structure: How Knowledge Heterogeneity Influences Managerial Performance and Innovativeness," Strategic Management Journal, 25 (6), 541-562.

Sasovova, Z., Mehra, A., Borgatti, S.P., and M.C. Schippers (2010). "Network Churn: The Effects of Self-Monitoring Personality on Brokerage Dynamics", Administrative Science Quarterly, 55(4), 639-670.

Scott, B.A. and T.A. Judge (2009). "The Popularity Contest at Work: Who Wins, Why, and What Do They Receive?," Journal of Applied Psychology, 94 (1), 20-33.

Seevers, M.T., Skinner, S.J., and R. Dahlstrom (2010). "Performance Implications of a Retail Purchasing Network: The Role of Social Capital", Journal of Retailing, 4, 310-321.

Shane, S., and D. Cable (2002). "Network Ties, Reputation, and the Financing of New Ventures", Management Science, 48, 364-381.

Shao J., Moser R., Lockstrom M., and I.L. Darkov (2008). "Process-Based Relational Perspective: A Framework for Buyer-Suplier Interactions," ICFAI Journal of Supply Chain Management, 5(4), 61-81.

Stam, W., and T. Elfring (2008). "Entrepreneurial Orientation and New Venture Performance: The Moderating role of Intra-and Extraindustry Social Capital," Academy of Management Journal, 51 (1), 97-111.

Stuart, T.E., H.Hoang, and R.C. Hybels (1999). "Interorganizational Endorsements and the Performance of Entrepreneurial Ventures," Administrative Science Quarterly, 44(2), 315349. 
Trusov, M., Bucklin, R., and K. Pauwels (2009). "Effects of Word-of-Mouth Versus Traditional Marketing: Findings from an Internet Social Networking Site", Journal of Marketing, 73(5), 90-102.

Uzzi, B. (1997). "Social Structure and Competition in Interfirm Networks: The Paradox of Embeddedness," Administrative Science Quarterly, 42 (1), 35-67.

Uzzi, B., and R. Lancaster (2003). "Relational Embeddedness and Learning: The Case of Bank Loan Managers and Their Clients," Management Science, 49 (4), 383-399.

Van Auken, H., Kaufmann, J., and P. Herrmann (2009). "An Empirical Analysis of the Relationship Between Capital Acquisition and Bankruptcy Laws", Journal of Small Business Management, 47(1), 23-37.

Vazire, S. (2010). "Who Knows What About a Person? The Self-Other Knowledge Asymmetry (SOKA) Model", Journal of Personality \& Social Psychology, 98 (2), 281-300.

Villanueva, J., Yoo, S., and D. Hanssens (2008). "The Impact of Marketing-Induced Versus Word-of-Mouth Customer Acquisition on Customer Equity Growth", Journal of Marketing Research, 45(1), 48-59.

Vissa, B., and A.S. Chacar (2009). "Leveraging Ties: The Contingent Value of Entrepreneurial Teams' External Advice Networks on Indian Software Venture Performance," Strategic Management Journal, 30, 1179-1191.

Wong, S.S., and W.F. Boh (2010). "Leveraging the Ties of Others to Build a Reputation for Trustworthiness among Peers," Academy of Management Journal, 53(1), 129-148.

Wong, P.L.K., and P. Ellis (2002). "Social Ties and Partner Identification in Sino-Hong Kong International Joint Ventures," Journal of International Business Studies, 33(2), 267-289.

Yli-Renko, H., and E.Autio (1998). "The Network Embeddedness of New, Technology-Based Firms: Developing a Systemic Evolution Model," Small Business Economics, 11(3), 253268.

Zhao, H., and S.E. Seibert (2006). "The Big Five Personality Dimensions and Entrepreneurial Status: A Meta-Analytical Review," Journal of Applied Psychology, 91, 259-271.

Zhou, L., W.P. Wu, and X. Luo (2007). "Internationalization and the Performance of Born-Global SMEs: The Mediating Role of Social Networks," Journal of International Business Studies, 38(4), 673-690.

Zhou, J., S. Jae Shin, D.J. Brass, J. Choi, and Z.X Zhang (2009). "Social Networks, Personal Values, and Creativity: Evidence for Curvilinear and Interaction Effects," Journal of Applied Psychology, 94(6), 1544-1552. 


\section{Appendix}

\section{Quality of Representation for Business Referrals}

\section{Retained items}

"People recommend my company to customers"

$\operatorname{Cos}^{2} \quad$ Var $\alpha$

"People strongly advise other firms to do business with my company"

$\begin{array}{lll}0.780 & 70 \% & 0.779\end{array}$

"My company obtains contracts thanks to favorable word of mouth"

0.747

0.580

\begin{tabular}{lccc}
\hline \multicolumn{4}{c}{ Quality of Representation for Agreeableness } \\
\hline Retained item label & Cos $^{2}$ & Var & $\boldsymbol{\alpha}$ \\
"I am interested in people" & 0.569 & $57 \%$ & 0.812 \\
"I sympathize with other people's feelings" & 0.561 & & \\
"I make time for others" & 0.624 & & \\
"I feel others' emotions" & 0.591 & & \\
"I make people feel at ease" & 0.514 & &
\end{tabular}

\begin{tabular}{lcll}
\hline \multicolumn{4}{c}{ Quality of Representation for Conscientiousness } \\
\hline Retained item label & Cos $^{2}$ & Var & $\boldsymbol{\alpha}$ \\
"I usually put things back in their proper place" & 0.744 & $69 \%$ & 0.774 \\
"I pay attention to detail" & 0.598 & & \\
"I like order" & 0.733 & & \\
\end{tabular}




\begin{tabular}{lcll}
\hline \multicolumn{4}{c}{ Quality of Representation for Extraversion } \\
\hline Item label & Cos $^{2}$ & Var & $\boldsymbol{\alpha}$ \\
"I do not talk a lot" & 0.636 & $58 \%$ & 0.760 \\
"I keep in the background" & 0.610 & & \\
"I start conversations" & 0.532 & & \\
"I talk to a lot of different people at parties" & 0.554 & & \\
& & & \\
\end{tabular}

\section{Quality of Representation for Openness to Experience}

\begin{tabular}{llll}
\hline Item label & $\mathbf{C o s}^{2}$ & $\mathbf{V a r}$ & $\boldsymbol{\alpha}$ \\
"I have a vivid imagination" & 0.715 & $68 \%$ & 0.757 \\
"I have excellent ideas" & 0.689 & & \\
"I am quick to understand things" & 0.639 & & \\
& & & \\
\hline
\end{tabular}




\begin{tabular}{|c|c|c|}
\hline & Number & Percentage \\
\hline \multicolumn{3}{|l|}{ Industry } \\
\hline Metal products & 103 & $25.25 \%$ \\
\hline Industrial machinery & 55 & $13.48 \%$ \\
\hline Electronic \& electrical equipment & 98 & $24.02 \%$ \\
\hline Chemicals, rubber \& plastic products & 75 & $18.38 \%$ \\
\hline Other manufacturing industries & 77 & $18.87 \%$ \\
\hline \multicolumn{3}{|l|}{ Firm size } \\
\hline Fewer than 10 employees & 180 & $44.12 \%$ \\
\hline 10 to 50 employees & 160 & $39.22 \%$ \\
\hline 50 to 250 employees & 68 & $16.67 \%$ \\
\hline \multicolumn{3}{|l|}{ CEO education } \\
\hline Graduate degree & 195 & $47.79 \%$ \\
\hline Undergraduate degree & 117 & $28.68 \%$ \\
\hline No undergraduate degree & 96 & $23.53 \%$ \\
\hline \multicolumn{3}{|l|}{ CEO gender } \\
\hline Women & 82 & $20.10 \%$ \\
\hline Men & 326 & $79.90 \%$ \\
\hline \multicolumn{3}{|c|}{ CEO tenure (number of years with the company) } \\
\hline Less than 2 years & 19 & $4.66 \%$ \\
\hline 2 to 5 years & 63 & $15.44 \%$ \\
\hline 5 to 10 years & 93 & $22.79 \%$ \\
\hline More than 10 years & 233 & $57.11 \%$ \\
\hline Mean & 12.618 & \\
\hline Standard deviation & 9.2741 & \\
\hline
\end{tabular}


Table 2 Means, Standard Deviations and Correlations

\begin{tabular}{|c|c|c|c|c|c|c|c|c|c|c|c|}
\hline & & 1 & 2 & 3 & 4 & 5 & 6 & 7 & 8 & 9 & 10 \\
\hline 1 & Business referrals & 1 & & & & & & & & & \\
\hline 2 & Gender (1=woman) & -0.022 & 1 & & & & & & & & \\
\hline 3 & Tenure (ln) & -0.045 & -0.060 & 1 & & & & & & & \\
\hline 4 & Graduate degree & -0.013 & -0.048 & $-0.190 * * *$ & 1 & & & & & & \\
\hline 5 & Undergraduate degree & -0.006 & $0.091 *$ & 0.047 & $-0.620 * * *$ & 1 & & & & & \\
\hline 6 & Metal products & 0.009 & 0.000 & $0.164 * * *$ & -0.065 & 0.021 & 1 & & & & \\
\hline 7 & Industrial machinery & 0.036 & -0.063 & -0.045 & -0.015 & 0.028 & $-0.105 * *$ & 1 & & & \\
\hline 8 & Electronic \& electrical equipment & 0.015 & $-0.122 * *$ & 0.005 & 0.068 & $-0.089 *$ & $-0.140 * * *$ & $-0.097 * *$ & 1 & & \\
\hline 9 & Chemicals, rubber \& plastic products & $-0.140 * * *$ & -0.017 & 0.024 & 0.047 & -0.15 & $-0.125 * *$ & $-0.087 *$ & $-0.115^{* *}$ & 1 & \\
\hline 10 & Fewer than 10 employees & -0.016 & $0.176^{* * *}$ & $-0.192 * * *$ & -0.023 & -0.026 & $-0.256 * * *$ & -0.040 & 0.041 & -0.034 & 1 \\
\hline 11 & 10 to 50 employees & -0.028 & $-0.103 * *$ & $0.127 * * *$ & -0.053 & 0.034 & $0.179 * * *$ & 0.008 & 0.006 & 0.049 & $-0.743 * * *$ \\
\hline 12 & $\mathbf{x}$ & 0.056 & -0.042 & $-0.095^{*}$ & 0.070 & -0.030 & $0.089 *$ & -0.053 & $-0.091 *$ & -0.003 & -0.067 \\
\hline 13 & Strength of ties & $0.127 * * *$ & 0.031 & 0.048 & 0.034 & -0.066 & -0.006 & -0.058 & 0.031 & 0.000 & $0.100 * *$ \\
\hline 14 & Agreeableness & $0.230 * * *$ & 0.061 & $-0.110 * *$ & -0.027 & -0.030 & 0.047 & 0.000 & -0.047 & $-0.086^{*}$ & 0.028 \\
\hline 15 & Conscientiousness & $0.152 * * *$ & $0.094^{*}$ & $-0.083^{*}$ & -0.064 & 0.032 & -0.065 & 0.036 & -0.007 & $-0.089 *$ & 0.074 \\
\hline 16 & Extraversion & $0.264 * * *$ & 0.014 & $-0.113 * *$ & 0.011 & -0.042 & 0.036 & 0.052 & -0.032 & -0.040 & -0.003 \\
\hline \multirow[t]{4}{*}{17} & Openness to experience & $0.344 * * *$ & -0.018 & $-0.081 *$ & $0.130 * * *$ & $-0.094 *$ & 0.027 & 0.045 & -0.020 & -0.043 & $0.092 *$ \\
\hline & $\mathbf{N}$ & 408 & 408 & 408 & 408 & 408 & 408 & 408 & 408 & 408 & 408 \\
\hline & Mean & 0.000 & 0.201 & 0.960 & 0.478 & 0.287 & 0.252 & 0.135 & 0.240 & 0.184 & 0.441 \\
\hline & Standard deviation & 1.000 & 0.398 & 0.380 & 0.500 & 0.457 & 0.338 & 0.252 & 0.319 & 0.291 & 0.498 \\
\hline
\end{tabular}




\begin{tabular}{|c|c|c|c|c|c|c|c|c|}
\hline & & 11 & 12 & 13 & 14 & 15 & 16 & 17 \\
\hline 11 & 10 to 50 employees & 1 & & & & & & \\
\hline 12 & Structural holes & 0.070 & 1 & & & & & \\
\hline 13 & Strength of ties & -0.076 & $-0.343 * * *$ & 1 & & & & \\
\hline 14 & Agreeableness & -0.069 & -0.051 & $0.099 * *$ & 1 & & & \\
\hline 15 & Conscientiousness & $-0.088^{*}$ & 0.007 & -0.019 & $-0.189 * * *$ & 1 & & \\
\hline 16 & Extraversion & -0.049 & 0.037 & $0.112 * *$ & $0.206 * * *$ & $0.093^{*}$ & 1 & \\
\hline \multirow[t]{4}{*}{17} & Openness to experience & -0.049 & -0.029 & $0.085^{*}$ & $0.224 * * *$ & 0.084 & $0.166^{* * *}$ & 1 \\
\hline & $\mathbf{N}$ & 408 & 408 & 408 & 408 & 408 & 408 & 408 \\
\hline & Mean & 0.392 & 0.000 & 0.000 & 0.000 & 0.000 & 0.000 & 0.000 \\
\hline & Standard deviation & 0.490 & 0.196 & 0.530 & 0.978 & 0.981 & 1.003 & 0.987 \\
\hline
\end{tabular}


Table 3 Hierarchical regression analysis

\begin{tabular}{|c|c|c|c|c|}
\hline & \multicolumn{4}{|c|}{ Business referrals (standardized coefficients, with Student statistics in brackets) ${ }^{8}$} \\
\hline & Model 1 & Model 2 & Model 3 & Model 4 \\
\hline Gender (1=woman) & $-0.015(-0.286)$ & $-0.012(-0.239)$ & $-0.011(-0.245)$ & $-0.002(-0.033)$ \\
\hline Tenure & $-0.055(-1.042)$ & $-0.055(-1.048)$ & $-0.009(-0.184)$ & $-0.019(-0.392)$ \\
\hline Graduate degree & $-0.039(-0.584)$ & $-0.049(-0.746)$ & $-0.054(-0.893)$ & $-0.068(-1.110)$ \\
\hline Undergraduate degree & $-0.041(-0.638)$ & $-0.039(-0.613)$ & $-0.001(-0.015)$ & $-0.024(-0.411)$ \\
\hline Metal products & $0.000(0.008)$ & $-0.010(-0.194)$ & $-0.037(-0.767)$ & $-0.060(-1.247)$ \\
\hline Industrial machinery & $0.021(0.408)$ & $0.032(0.633)$ & $0.015(0.323)$ & $0.022(0.490)$ \\
\hline Electronic \& electrical equipment & $0.007(0.129)$ & $0.013(0.257)$ & $0.030(0.636)$ & $0.018(0.375)$ \\
\hline Chemicals, rubber \& plastic products & $-0.132 * *(-2.575)$ & $-0.128 * *(-2.525)$ & $-0.099 * *(-2.129)$ & $-0.098 * *(-2.062)$ \\
\hline Fewer than 10 employees & $-0.082(-1.041)$ & $-0.101(-1.295)$ & $-0.114(-1.575)$ & $-0.111(-1.567)$ \\
\hline 10 to 50 employees & $-0.080(-1.068)$ & $-0.088(-1.180)$ & $-0.070(-1.022)$ & $-0.069(-1.010)$ \\
\hline Structural holes & & $0.113 * *(2.099)$ & $0.095 *(1.926)$ & $0.087 *(1.745)$ \\
\hline Strength of ties & & $0.174 * * *(3.254)$ & $0.110 * *(2.233)$ & $0.120 * *(2.451)$ \\
\hline Agreeableness & & & $0.109 * *(2.273)$ & $0.089 *(1.825)$ \\
\hline Conscientiousness & & & $0.102 * *(2.194)$ & $0.077 *(1.678)$ \\
\hline Extraversion & & & $0.163 * * *(3.481)$ & $0.149 * * *(3.151)$ \\
\hline Openness to experience & & & $0.287 * * *(6.062)$ & $0.325 * * *(6.838)$ \\
\hline Strength of ties $\mathrm{X}$ agreeableness & & & & $-0.077(-1.458)$ \\
\hline Strength of ties $\mathrm{X}$ conscientiousness & & & & $-0.120 * *(-2.330)$ \\
\hline Strength of ties $\mathrm{X}$ extraversion & & & & $-0.030(-0.583)$ \\
\hline Strength of ties X openness to exp. & & & & $0.067(1.284)$ \\
\hline Structural holes X agreeableness & & & & $-0.029(-0.555)$ \\
\hline Structural holes $\mathrm{X}$ conscientiousness & & & & $-0.219 * * *(-4.158)$ \\
\hline Structural holes X extraversion & & & & $0.001(0.011)$ \\
\hline Structural holes X openness to exp. & & & & $-0.006(-0.112)$ \\
\hline $\mathrm{R}^{2}$ & 0.026 & 0.054 & 0.219 & 0.263 \\
\hline Adjusted $\mathrm{R}^{2}$ & 0.001 & 0.025 & 0.187 & 0.217 \\
\hline $\mathrm{R}^{2}$ variation & 0.026 & 0.028 & 0.166 & 0.043 \\
\hline Standard error estimate & 0.995 & 0.984 & 0.898 & 0.882 \\
\hline $\mathrm{F}$ & 1.056 & $1.861^{* *}$ & $6.852 * * *$ & $5.677 * * *$ \\
\hline $\mathrm{N}$ & 408 & 408 & 408 & 408 \\
\hline
\end{tabular}

\footnotetext{
${ }^{8}$ Student $\mathrm{t}$ significance: $* * * \mathrm{p}<0.01 ; * * \mathrm{p}<0.05 ; * 0.05<\mathrm{p}<0.10$
} 


\section{Table 4 Synopsis of Results}

\section{Direct effect of social capital on business referrals}

H1: The higher the number of structural holes in an SME CEO's network, the more Supported business referrals he/she will obtain.

H2: The stronger the ties in an SME CEO's network, the more business referrals

Supported he/she will obtain.

\section{Direct effect of positive personality on business referrals}

H3a: The more an SME CEO is agreeable, the more business referrals he/she will

Supported obtain.

$\mathrm{H} 3 \mathrm{~b}$ : The more an SME CEO is conscientious, the more business referrals he/she

Supported will obtain.

H3c: The more an SME CEO is extraverted, the more business referrals he/she will Supported obtain.

$\mathrm{H} 3 \mathrm{~d}$ : The more an SME CEO is open to experience, the more business referrals

Supported he/she will obtain.

\section{Positive personality moderating the effect of social capital}

\section{Structural holes}

H4a: The positive relationship between structural holes and business referrals is

Not supported stronger when an SME CEO is low on agreeableness

$\mathrm{H} 4 \mathrm{~b}$ : The positive relationship between structural holes and business referrals is

Supported stronger when an SME CEO is low on conscientiousness.

H4c: The positive relationship between structural holes and business referrals is

Not supported stronger when an SME CEO is low on extraversion.

H4d: The positive relationship between structural holes and business referrals is

Not supported stronger when an SME CEO is low on openness to experience.

\section{Strength of ties}

H5a: The positive relationship between strength of ties and business referrals is

Not supported stronger when an SME CEO is low on agreeableness

$\mathrm{H} 5 \mathrm{~b}$ : The positive relationship between strength of ties and business referrals is

Supported stronger when an SME CEO is low on conscientiousness.

H5c: The positive relationship between strength of ties and business referrals is

Not supported stronger when an SME CEO is low on extraversion.

H5d: The positive relationship between strength of ties and business referrals is stronger when an SME CEO is low on openness to experience. 